\title{
Biological control of leafy spurge with introduced flea beetles (Aphthona spp.)
}

\author{
DONALD R. KIRBY, ROBERT B. CARLSON, KELLY D. KRABBENHOFT, DONALD MUNDAL, AND MATT M. \\ KIRBY
}

Authors are professor, Animal and Range Sciences Department, North Dakota State University, Fargo, N.D. 58105; professor, Entomology Department, North Dakota State University, Fargo, N.D. 58105; research specialist, Animal and Range Sciences Department, North Dakota State University, Fargo, N.D. 58105; research specialist, Entomology Department, North Dakota State University, Fargo, N.D. 58105; and undergraduate student, Animal and Range

Astract

Flea beetles (Aphthona spp.) were introduced into leafy spurge (Euphorbia esula L.)-infested rangeland in east-central North Dakota. The study objectives were to evaluate the effects of the introduced insects on leafy spurge cover, density, and yield, and grass and grass-like yield of associated plant communities. Aphthona spp. were released in 1988 and 1989 at 2 sites near Valley City, N.D. Aboveground vegetative sampling for leafy spurge cover, density and yield, and grass and grass-like yield was conducted between 1993 and 1995. Belowground sampling of root density, dry weight and root buds was conducted between the release date and 1995. Aphthona spp. reduced aboveground cover, density and yield of leafy spurge and increased yield of grass and grass-like species. Leafy spurge root density, weight, and number of root buds decreased on insect release sites between release dates and 1995 . Reduced stem density of leafy spurge and increased grass and grass-like yield, should enhance cattle use and production from these sites.

Key Words: biological control, leafy spurge, insects, flea beetles, range improvement

Biological control of introduced noxious weeds using insects has received limited use on rangelands (Vallentine 1989). Successful biological control efforts using insects has been reported for St. John's-Wort (Hypericum perforatum L.) (Huffaker and Kennett 1959), pricklypear (Opuntia spp.) (Goeden et al. 1968), and tansy ragwort (Senecio jacobaea L.) (Hawkes 1968). Efforts to control leafy spurge (Euphorbia esula L.) with insects has been ongoing since the 1960s with significant expansion in the 1970 s and 1980s (Harris 1984, Pemberton 1985).

Leafy spurge is an introduced plant from Eurasia that is extremely persistent and competitive in grazed rangelands (Dunn 1979). It is considered a prime candidate for biological control because of its propensity to invade a variety of habitats such as grasslands, woodlands, riparian areas and waterways where alternative control efforts may be limited and it is a perennial weed providing a continuous source of food to organisms capable of utilizing portions of the plant. Unfortunately, leafy spurge's defense mechanisms such as the milky latex make utilization of the plant difficult except for well adapted insects that have evolved means to overcome these defenses (Best et al. 1980).

Manuscript accepted 17 Aug. 1999.
Resumen

Se introdujeron "Flea beetles" (Aphthona spp.) en pastizales de la región centro-este de North Dakota los cuales estaban infestados con "leafy spurge" (Euphorbia esula L.). Los objetivos del estudio fueron evaluar los efectos de los insectos introducidos en la cobertura, densidad y rendimiento del "Leafy spurge" y en el rendimiento de zacates y planta similares a los zacates de las comunidades vegetales asociadas. Los Aphthona spp. Se liberaron en 1988 y 1989 en 2 sitios cerca de Valley City, N.D. El muestreo de las partes vegetativas aéreas para determinar cobertura, densidad y rendimiento del "Leafy spurge" y el rendimiento de los zacates y plantas similares a zacates se condujo entre 1993 y 1995. El muestreo de las partes subterráneas para determinar la densidad y peso seco de raíces y yemas radicales se condujo entre la fecha de liberación de los insectos y 1995. Las especies de Aphthona redujeron la cobertura, densidad y rendimiento de "leafy spurge" e incrementaron el rendimiento de las especies de zacates y plantas similares a ellos. La densidad de raíces de "Leafy spurge", el peso y numero de yemas radicales disminuyo entre la fecha de liberación y 1995 en los sitios en donde se liberaron los insectos. La reducción de tallos de "Leafy spurge" y el aumento del rendimiento de zacates y plantas similares a estos debe incrementar el uso de ganado bovino y la producción en estos sitios.

Eight insects have been released to control leafy spurge in North Dakota since the 1980s (Lym and Zollinger 1995). Of these, flea beetles (Aphthona spp.) have been the most successful for establishment, reproduction and redistribution. However, limited quantitative information is available regarding the impact of Aphthona spp. on leafy spurge and the associated plant community. The objectives of this study were to evaluate the effects of Aphthona spp. on leafy spurge cover, density and yield, and grass and grass-like yield of associated plant communities.

\section{Material and Methods}

Experiments to evaluate leafy spurge control with an introduced biological control agent Aphthona spp. were established at 2 sites in east-central North Dakota. A total of 80 flea beetles were released in 1988 at a site that was approximately $15 \mathrm{~km}$ northwest of Valley City (North) on the Katie Olson Wildlife Management Area $\left(98^{\circ} 10^{\prime} \mathrm{N} 47^{\circ} 15^{\prime} \mathrm{W}\right)$. Biological control agents at this site were 
2 flea beetle species, A. czwalinae and A.lac ertosa. A second site was located approximately $15 \mathrm{~km}$ southeast of Valley City (South) on private land $\left(97^{\circ} 50^{\prime} \mathrm{N} 46^{\circ} 50^{\prime} \mathrm{W}\right)$. Approximately 1,000 A. nigriscutis were released at this site in 1989.

Both sites are located within the Sheyenne River drainage system, which is highly dissected and steeply sloping $(>15 \%)$. Soils were a Koten silty clay loam (fine, montmorillonitic Udertic Haploboroll) at the North site and a Nutley silty clay (loamy, mixed Lithic Haploboroll) at the South site. Both sites supported northern mixed grass prairie (Barker and Whitman 1989) with infestations of leafy spurge exceeding $200 \mathrm{stems} / \mathrm{m}^{2}$. Annual average precipitation for east-central North Dakota is $45 \mathrm{~cm}$ with approximately $75 \%$ received during the growing season (April through September). Annual precipitation received between 1988 and 1995 was similar to the long-term average, $50 \mathrm{~cm}$, with $80 \%$ occurring during the growing season.

Aboveground vegetative sampling was initially conducted at the North experiment in 1988. Sampling was abandoned after 1990 because the insect colony migrated to an adjacent area. Vegetative sampling resumed between 1993 and 1995 after the insect colony became permanently established. Vegetative sampling was initiated in 1993 at the South experiment to allow time for the insect colony to permanently establish. Three random transects each were located in insect colonized and insect free areas at both study sites. Leafy spurge cover and density were estimated from eight $0.1 \mathrm{~m}^{2}$ quadrats positioned randomly along each transect. Leafy spurge, and grass and grass-like yields were determined by clipping and drying $\left(60^{\circ} \mathrm{C}\right)$ the vegetation within four, $0.1 \mathrm{~m}^{2}$ quadrats along each transect. Vegetative measurements were conducted at the peak standing crop in late July each year.

Soil samples for root characterization were initiated in 1988 at the North site and 1989 at the South site. At North and South sites, 4 and 3 random transects were placed at insect colonized and insect free areas, respectively. The insect free transect sampling was terminated at both study locations in 1991 due to movement of the insects into these areas. On each transect, 5 random soil cores $15-\mathrm{cm}$ deep (12-cm diameter) were collected using a $12-\mathrm{cm}$ diameter golf cup-cutter each October and stored in plastic bags at $-4^{\circ} \mathrm{C}$. The leafy spurge roots from each core were extracted from the soil and washed. The number of individual root segments and root buds for each segment were recorded. The root

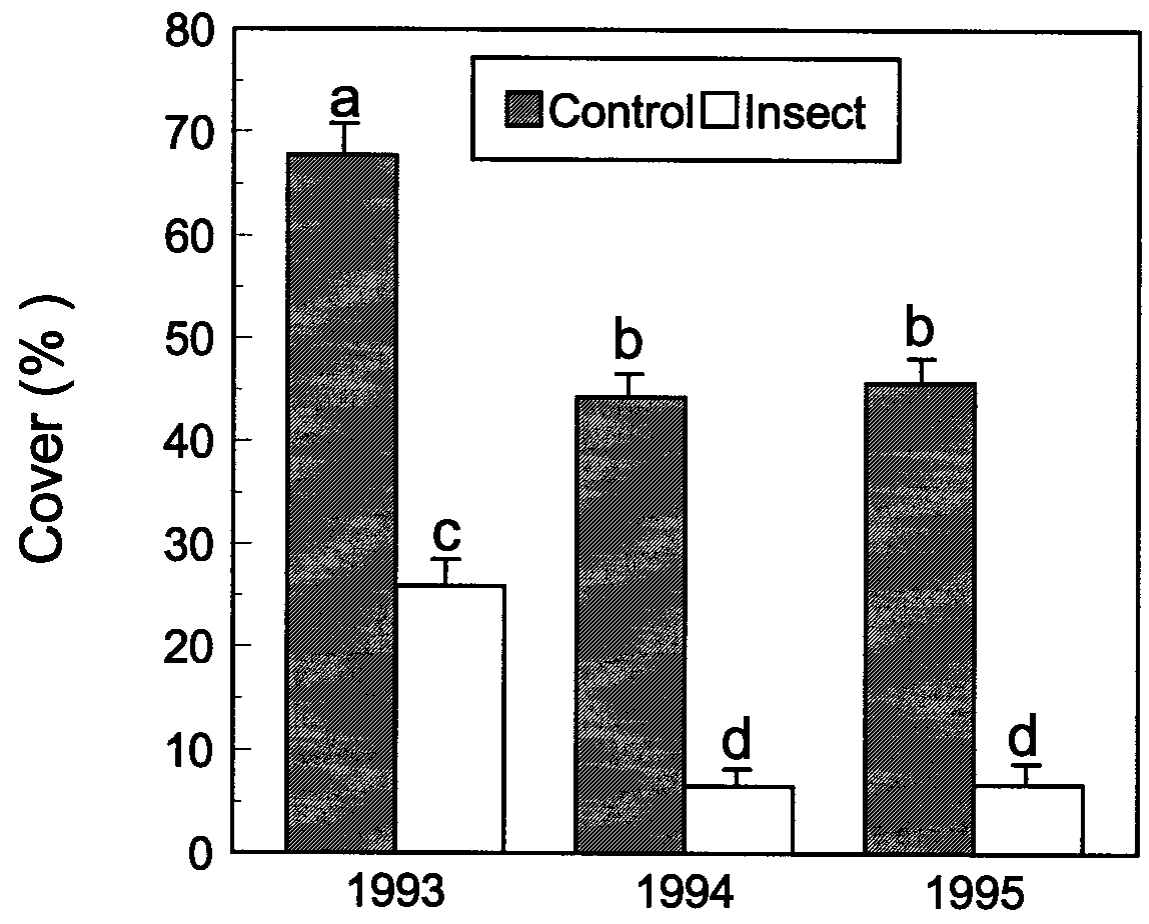

Fig. 1. Leafy spurge cover (\%) following Aphthona spp. colonization of leafy spurge-infested rangeland. Bars with different letters differ $(P<0.05)$.

segments were then dryed at $60^{\circ} \mathrm{C}$ for dry weight determinations.

The effect of flea beetle control on leafy spurge was evaluated as a randomized complete block design at 2 locations with 3 blocks (transects) and 2 treatments (insect free and insect colonized). Blocks were found to be nonsignificant between locations so a completely randomized design was utilized. Vegetative and root data by treatment and year were analyzed using a one-way ANOVA (SPSS, Inc. 1994) and mean differences were considered significant at the $5 \%$ probability level using Tukey's h test.

\section{Results and Discussion}

Foliar cover of leafy spurge was reduced ( $\mathrm{P}<0.05)$ on Aphthona spp. colonized sites compared to insect free sites (Fig. 1). Pre-treatment estimates (1988) of leafy spurge cover were $45 \%$ (data not shown) which was similar to the control sites in 1994 and 1995. A 6- to 7-fold decrease in leafy spurge cover occurred on release sites over this same time period. Stromme et al. (1996) reported a similar reduction in leafy spurge foliar cover, $40 \%$ to $1.7 \%$, five years after $A$. nigriscutis were released near Edmonton, Canada.

Leafy spurge stem densities were reduced on Aphthona spp. release sites compared to pre-study estimates $\left(218 / \mathrm{m}^{2}\right)$ and control sites (Fig. 2). By 1994, Aphthona spp. had reduced leafy spurge stem densities nearly 40 -fold to only $5 / \mathrm{m}^{2}$. Stem density reductions have also been reported by Hansen (1993), Baker et al. (1996), Lym et al. (1996) and Stromme et al. (1996). However, only Stromme et al. (1996) reported reductions in leafy spurge stem densities of the magnitude evaluated in this study.

Stem densities of leafy spurge have been reported to influence cattle grazing behavior (Lym and Kirby 1987). Stem densities exceeding $100 / \mathrm{m}^{2}$ decreased cattle use of leafy spurge-infested rangeland. Leafy spurge stem densities on insect release sites were reduced to a level that would allow cattle grazing.

Total herbaceous yields were greater on control sites compared to the insect release sites each year due to the biomass contribution from leafy spurge (Table 1). Leafy spurge biomass was reduced each year on the insect release sites compared to the controls, while graminoid yields were greater on Aphthona spp. release sites in 1994 and 1995 compared to the controls. Stromme et al. (1996) reported a decrease in leafy spurge biomass from 1,730 to 17 $\mathrm{kg} / \mathrm{ha}$ and an increased grass biomass from 14 to $433 \mathrm{~kg} / \mathrm{ha}$ which are comparable to those reported in this study. 
Table 1. Herbage yield ( $\overline{\mathrm{x}} \pm$ S.E.) on 2 Aphthona spp. release sites in eastern North Dakota.

\begin{tabular}{lccc}
\hline \hline Year & Grass and Grass-like & Leafy Spurge & Total Herbaceous \\
\hline \multicolumn{4}{c}{} \\
1993 & $919 \pm 177 \mathrm{a}^{1}$ & INSECT FREE \\
1994 & $1067 \pm 107 \mathrm{a}$ & $3381 \pm 255 \mathrm{a}$ & $4300 \pm 229 \mathrm{a}$ \\
1995 & $998 \pm 103 \mathrm{a}$ & $1140 \pm 115 \mathrm{~b}$ & $2207 \pm 144 \mathrm{~b}$ \\
& & $1248 \pm 95 \mathrm{~b}$ & $2246 \pm 198 \mathrm{~b}$ \\
1993 & $1041 \pm 100 \mathrm{a}$ & INSECT COLONIZED & \\
1994 & $1612 \pm 189 \mathrm{~b}$ & $742 \pm 57 \mathrm{c}$ & $1783 \pm 11 \mathrm{c}$ \\
1995 & $1526 \pm 147 \mathrm{~b}$ & $105 \pm 39 \mathrm{~d}$ & $1717 \pm 188 \mathrm{c}$ \\
\hline
\end{tabular}

${ }^{\mathrm{T}}$ Means in a column followed by a different letter differ $(\mathrm{P}<0.05)$.
Grass and grass-like yield increased approximately $50 \%$ on Aphthona spp. colonized sites compared to insect free sites. However, yields were lower than sites without leafy spurge infestation (Table 1). Silty and clayey range sites in this vegetation zone would be expected to produce $2,600 \mathrm{~kg} / \mathrm{ha}$ under average environmental inputs (USDA, SCS 1984). However, leafy spurge stem densities on insect colonized sites were reduced below 100 stems $/ \mathrm{m}^{2}$; therefore, normal cattle foraging activities would be expected to occur on these sites. Given average stocking rates for these range sites without leafy spurge infestation (2.2 AUM/ha) and the forage yields as reported in this study, stocking rates would be $1.3 \mathrm{AUM} / \mathrm{ha}$ of treated leafy spurge.

The authors can only speculate about the delay in recolonization of the study sites by native grass and grass-like species. A seed source for these species may be lacking in the soil in areas with a long-term domination by leafy spurge. Most native graminoid species in the northern Great Plains rely on vegetative reproduction, while seed production is erratic and viability is low. Evidence indicates that leafy spurge may also have allelopathic characteristics that may reduce germination and establishment of native graminoid species (Steenhagen and Zimdahl 1979). Soil seed banks for long-term leafy spurge infested sites are presently being investigated. In addition, there was a lack of competitive, cool-season grass species such as Kentucky bluegrass (Poa pratensis L.) and smooth brome (Bromus inermis Leyss.) on the study sites. These species have been reported to rapidly increase and dominate forage production on numerous sites in North Dakota when leafy spurge density has been controlled (Lym and Kirby 1987, Lym and Messersmith 1994, Kirby et al. 1997, Lym et al. 1997). Finally, as evidenced by the belowground biomass data (Fig. 3), leafy spurge is still present on the sites and competing for limited growth resources such as moisture and nutrients. This competition for resources may be playing a role in suppressing the establishment and survival of graminoid seedlings and vegetative recolonization of the study sites.

Leafy spurge root density, weight and number of root buds decreased on Aphthona spp. colonized sites between 1988 and 1995 (Fig. 3). Data for insect free sites is not available as the Apthona spp. migrated through the root-harvest control transects. Aphthona larvae feed on the root system of leafy spurge when soil temperatures exceed $9^{\circ} \mathrm{C}$ and emerge as adults in early summer. Root biomass reduction is probably the main causative agent in the decrease in aboveground cover and density of leafy spurge on the sites. Despite a significant reduction in root bud number over the 7 to 8 years of the study, 10 to 15 root buds per $10 \mathrm{~cm}^{2}$ of topsoil remained. Given the number of root buds in the topsoil, leafy spurge could rapidly recolonize a site without the continued presence of the Aphthona spp.

\section{Conclusions}

The introduction of Aphthona spp. into leafy spurge-infested rangeland resulted in decreased cover, density and biomass of leafy spurge and increased yield of grass and grass-like species. Significant reductions in leafy spurge root biomass occurred within 2 to 3 years, yet beneficial aboveground changes occurred only after 5 years following insect colonization. Grass and grass-like yield had not recovered after 7 to 8 years following insect colonization.

The results of this study should not be interpreted too broadly. Only 3 of 8 Aphthona spp. were released with soils limited to silty/clayey on steep sideslopes in this study. Nowierski et al. (1996) characterized habitat associations for leafy spurge and flea beetles in Europe, yet little is known of the establishment and habitat

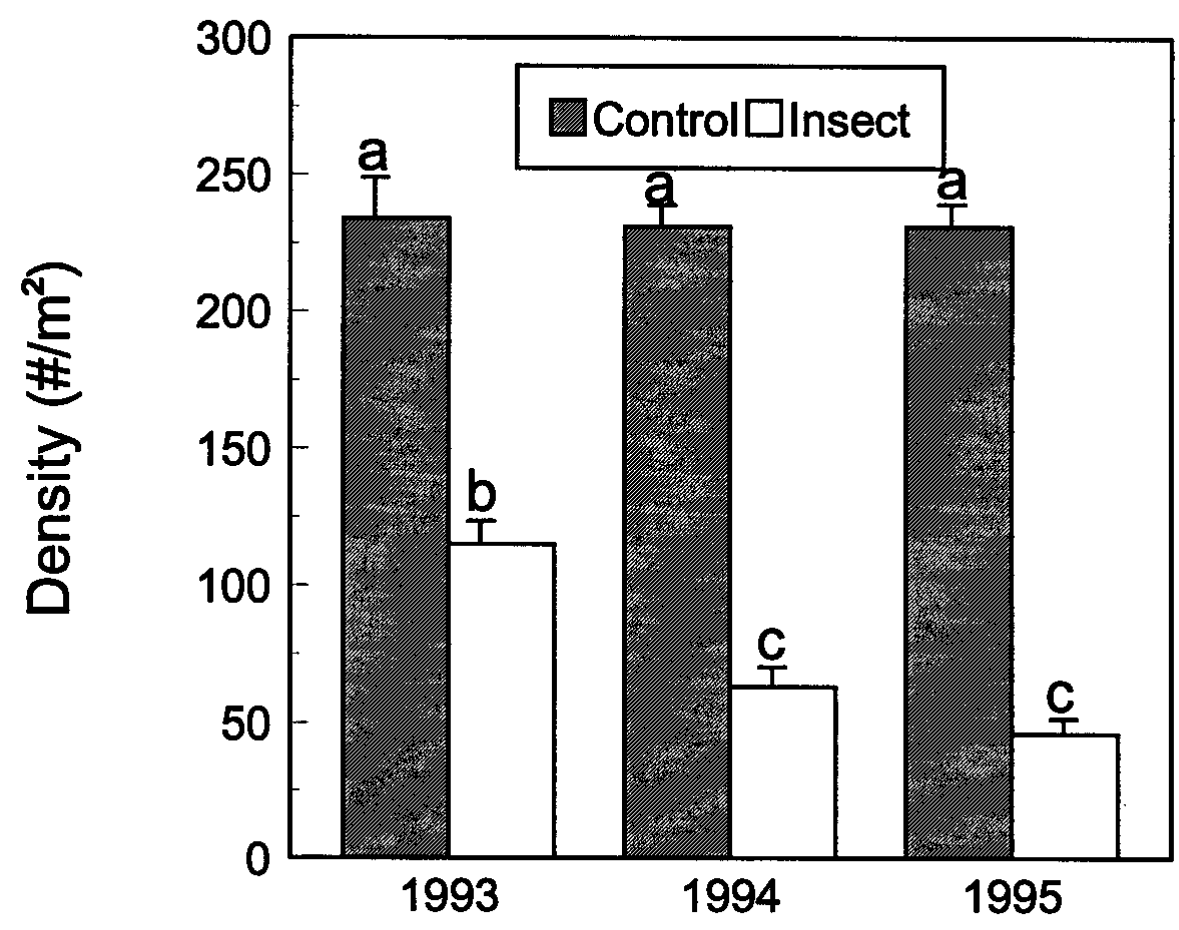

Fig. 2. Leafy spurge density $\left(\# / \mathrm{m}^{2}\right)$ following Aphthona spp. colonization of leafy spurgeinfested rangeland. Bars with different letters differ $(P<\mathbf{0 . 0 5})$. 


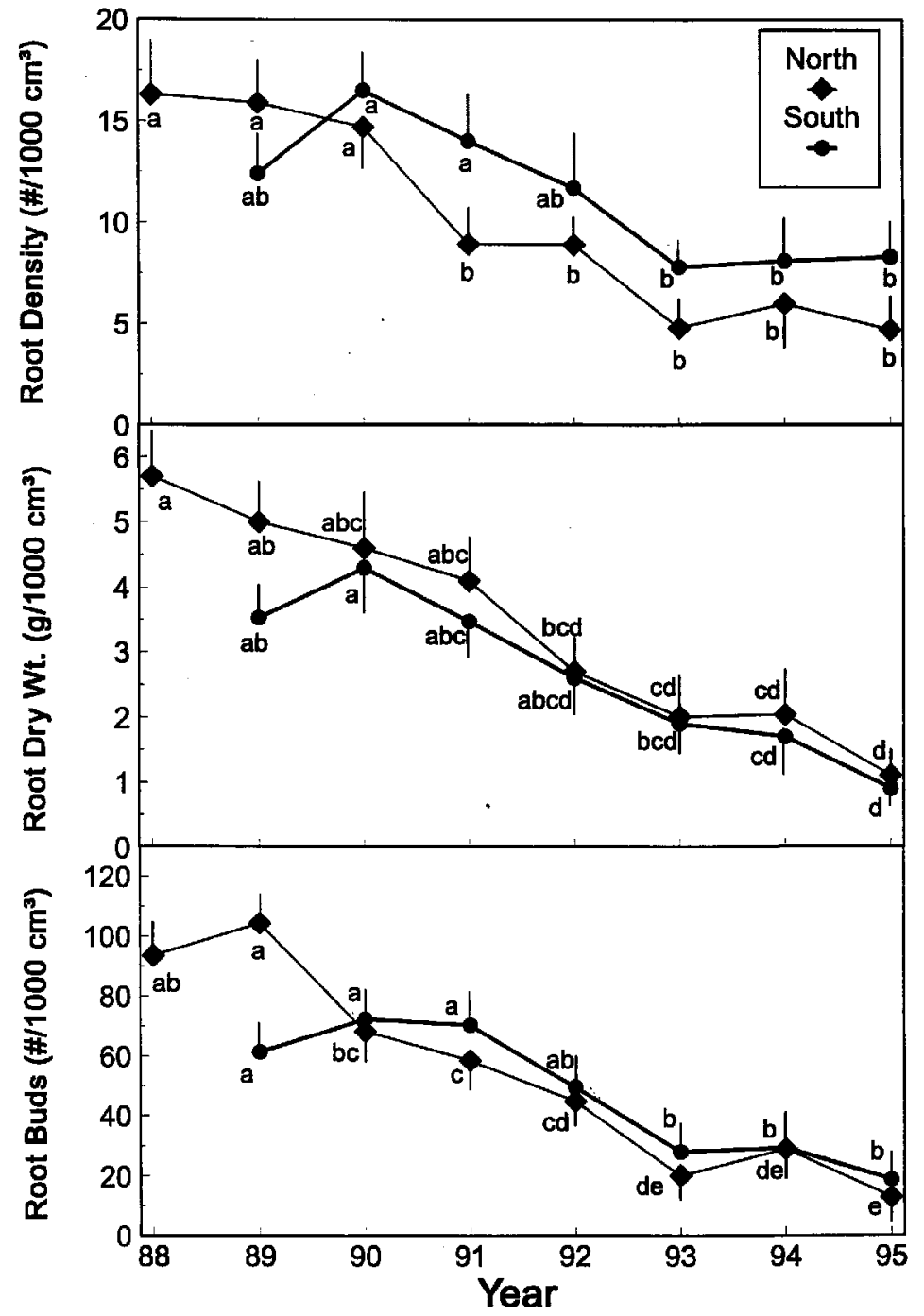

Fig. 3. Root density, dry weight and root buds $(\bar{x} \pm$ S.E. $)$ from soil cores at 2 locations following Aphthona spp. colonization of leafy spurge-infested rangeland. Means by location followed by a different letter differ $(P<0.05)$.

requirements of Aphthona spp. in North America. Aphthona spp. establishment in sandy soils, overflow or subirrigated range sites, and in shrubby or riparian areas have not been successful to date. Questions concerning successful establishment procedures and habitat barriers such as soil, slope, aspect, root demographics, leafy spurge density, surface litter, initial release sizes, over-winter survival, population size, persistence, rate of spread and more remain to be answered.

\section{Literature Cited}

Baker, J.L., N.A.P. Webber, K.K. Johnson, and R.L. Lavigne. 1996. The behavior of Aphthona nigriscutis and the response of leafy spurge over a four year period in
Fremont county Wyoming. Proc. Western Soc. Weed Sci. 49:47-48.

Barker, W.T. and W.C. Whitman. 1989. Vegetation of the Northern Great Plains. Rangelands 10:266-272.

Best, K.F., G.G. Bowes, A.G. Thomas, and M.G. Maw. 1980. The biology of Canadian weeds. 39. Euphorbia L. Canadian J. Plant Sci. 60:651-663.

Dunn, P.H. 1979. The distribution of leafy spurge and other Euphorbia spp. in the United States. Weed Sci. 27:509-516.

Goeden, R.D., C.A. Fleschner, and D.W. Ricker. 1968. Insects control prickly-pear cactus. Calif. Agr. 22:8-9.

Hansen, R. 1993. Effects of Aphthona flea beetles and sheep grazing in leafy spurge stands. p. 47-48. In: K.G. Beck (ed.) Proc. Leafy Spurge Symp., Silvercreek, Colo.

Harris, P. 1984. Euphorbia esula-virgata complex, leafy spurge and E. cyparissias L. cypress spurge (Euphorbiaceae), p. 159-169.
In: J.S. Kelleher and M.A. Hulme (eds.), Biological control programs against insects and weeds in Canada 1969-80. Farnham Agr. Bur. Farnham Royal, U.K.

Hawkes, R.B. 1968. The cinnabar moth, Tyria jacobaceae, for control of tansy ragwort. J. Econ. Entomol. 61:499-501.

Huffaker, C.B. and C.E. Kennett. 1959. Tenyear study of vegetational changes associated with biological control of Klamath weed. J. Range Manage. 12:69-82.

Kirby, D.R., T.P. Hanson, K.D. Krabbenhoft, and M.M. Kirby. 1997. Effects of simulated defoliation of leafy spurge (Euphorbia esula)infested rangeland. Weed Tech. 11:586-590.

Lym, R.G. and D.R. Kirby. 1987. Cattle foraging behavior in leafy spurge (Euphorbia L.) infested rangeland. Weed Tech. $1: 314-318$

Lym, R.G. and C.G. Messersmith. 1994. Leafy spurge (Euphorbia esula) control, forage production, and economic return with fall-applied herbicides. Weed Tech. 8:824-829.

Lym, R.G. and R.K. Zollinger. 1995. Integrated management of leafy spurge. North Dakota State Univ. Ext. Serv. Bull. W-866 (rev.). 4 pp.

Lym, R.G., K.K. Sedivec, and D.R. Kirby. 1997. Leafy spurge control with angora goats and herbicides. J. Range Manage. 50:123-128.

Lym, R.G., R.B. Carlson, K.M. Christianson, D.A. Mundal, and C.G. Messersmith. 1996. Integration of herbicides with Aphthona spp. flea beetles for leafy spurge control. p. 64. In: K. Pouteau (ed.), Proc. Leafy Spurge Symp., Brandon, Manitoba.

Nowierski, R.M., Z. Zeng., D. Schroeder, and A. Gassmann. 1996. Habitat analyses of Euphorbia species and associated flea beetles in the Aphthona complex from Europe: can we learn something about habitat associations of natural enemies prior to release? $\mathrm{p}$. 232. In: V.C. Moran and J.H. Hoffmann (eds.), Proc. IX Internat. Symp. Biol. Control Weeds, Stellenbosch, So Africa.

Pemberton, R.W. 1985. Native plant considerations in the biological control of leafy spurge. p. 365-390. In: E.S. Delfosse (ed.), Proc. VI Internat. Symp. Biol. Control Weeds, Vancouver, British Columbia.

SPSS, Inc. 1994. SPSS advanced statistics. 6.1. Chicago, Ill.

Steenhagen, D.A. and R.L. Zimdahl. 1979. Allelopathy of leafy spurge (Euphorbia). Weed Sci. 27:1-3.

Stromme, K., D.E. Cole, A.S. McClay, C.J. Richardson, and J. de Valois. 1996. Biocontrol of leafy spurge with Aphthona nigriscutis in Alberta "The Beverly Bridge Site. p. 26-27. In: K. Pouteau (ed.), Proc. Leafy Spurge Symp., Brandon, Manitoba.

USDA, SCS. 1984. Range Site Technical Guide Notice ND-35. Bismarck, N.D.

Vallentine, J.F. 1989. Range development and improvements. Academic Press, Inc., New York, N.Y.

\section{Abstract}

